\title{
UPAYA PENINGKATAN SADAR WISATA BERBASIS BAHASA DAN KEWIRAUSAHAAN PADA KEGIATAN PROMOSI KAMPUNG WISATA KUNGKUK
}

\author{
Esti Junining ${ }^{1)}$, Nila Firdausi Nuzula²), Isti Purwaningtyas ${ }^{3)}$, Didik Hartono ${ }^{1)}$, Nuria Setiarini'), \\ N'imatul Lailiyah'1)
1, 4, 5, 6) Pendidikan Bahasa Inggris, Fakultas IImu Budaya, Universitas Brawijaya, Malang, Jawa Timur, Indonesia
2) Administrasi Bisnis, Fakultas IImu Administrasi, Universitas Brawijaya, Malang, Jawa Timur, Indonesia
3) Sastra Inggris, Fakultas IImu Budaya, Universitas Brawijaya, Malang, Jawa Timur, Indonesia
Corresponding author : Esti Junining
E-mail : esti@ub.ac.id

Diterima 01 Oktober 2020, Direvisi 10 November 2020, Disetujui 10 November 2020

\begin{abstract}
ABSTRAK
Tujuan dari pengabdian kepada masyarakat ini adalah untuk memberikan dan menerapkan pengetahuan terkait kegiatan promosi berbasis Bahasa dan kewirausahaan masyarakat desa wisata. Metode yang digunakan untuk mencapai tujuan ini adalah ceramah bervariasi, demonstrasi, dan latihan. Pendampingan kegiatan pengabdian ini dilakukan secara luring dan daring. Kegiatan secara luring dilaksanakan secara sarahsehan dengan mentaati protocol kesehatan yang disarankan oleh pemerintah. Kegiatan luring terdiri dari pelatihan Bahasa Inggris, pelatihan promosi wirausaha, peluncuran aplikasi untuk latihan komunikasi Bahasa Inggris, pemasangan pelakat petunjuk arah sebagai promosi wisata serta kerjasama untuk menjadikan dusun-dusun lainnya menjadi dusun tematik dengan potensi wisata yang dimiliki. Kegiatan secara daring juga dilakukan pelatihan melalui aplikasi yang didesain khusus untuk pembelajaran komunikasi bagi penggiat wisata. Hasil dari pengabdian ini adalah peserta memahami dan dapat mempraktekkan secara langsung kegiatan promosi melalui Bahasa dan wirausaha untuk peningkatan kualitas pelayanan dan peningkatan kualitas ekonomi masyarakat lokal desa wisata.
\end{abstract}

Kata kunci: pengembangan desa wisata; sadar bahasa; sadar wisata; ekonomi lokal.

\begin{abstract}
The purpose of this community service is to provide and apply knowledge related to language-based promotion activities and entrepreneurship in tourism village communities. The methods used to achieve the goal are varied lectures, demonstrations, and exercises. Assistance for this service activity is carried out offline and online. Offline activities are carried out in a sarahsehan manner in accordance with the health protocol recommended by the government. Offline activities consist of English language training, entrepreneurial promotion training, launching applications for English communication training, installing direction signs as tourism promotions and cooperation to turn other hamlets into thematic hamlets with their tourism potential. Online activities are also conducted through training through applications specifically designed for communication learning for tourism activists. The result of this service is that participants understand and can directly practice promotional activities through language and entrepreneurship to improve service quality and improve the economic quality of local tourism village communities.
\end{abstract}

Keywords: tourism village development; language awareness; tourism awareness; local economy.

\section{PENDAHULUAN}

Desa wisata merupakan bentuk
pariwisata yang menggunakan dan memanfaatkan potensi alam pedesaan serta budaya setempat sebagai daya tarik wisata (Antara \& Arida, 2015). Dalam konteks kepariwisataan di Kota Batu, desa wisata turut memiliki andil sebagai salah satu penyumbang terbesar dalam hal perkembangan pariwisata. Kian maraknya keberadaan desa wisata di Kota Batu menunjukan semangat masyarakat dan pemerintah setempat sebagai generator pertumbuhan ekonomi lokal. Desa wisata hadir ke tengah persaingan pariwisata dan turut serta mewarnai maraknya tujuan wisata yang sedang trend dalam hal menonjolkan pengembangan bercorak mass tourism (Arida \& Pujani, 2017). Dalam perkembangannya, potensi-potensi tersebut harus diiringi oleh tersedianya kualitas sumber daya manusia yang baik. Oleh karena itu, perlu ditanamkan kesadaran masyarakat tentang pentingnya aspek-aspek yang 
menunjang keberlanjutan pariwisata desa (Sukma, 2014). Namun, keberlanjutan pariwisata desa tetap harus diiringi oleh beberapa komponen pendukung diantaranya adalah memiliki potensi wisata khas daerah setempat, masyarakat lokal memiliki antusiasme yang tinggi dalam pengembangan desa wisata, dan memiliki akses infrastruktur yang mendukung serta masih memungkinkan untuk dilakukan pengembangan (Sastrayuda, 2010; Samiarta \& Mahagangga, 2016).

Kampung wisata Kungkuk di Kota Batu merupakan salah satu dari empat dusun yang berasa di Desa Punten, Kecamatan Bumiaji, Kota Batu. Lokasi kampung wisata Kungkuk memiliki posisi yang sangat strategis karena berada pada pusat pengembangan agro Kota Wisata Batu. Kampung wisata ini menawarkan beberapa atraksi dan objek wisata yang menarik, diantaranya adalah peternakan dan perah sususapi, pertanian jambu, peternakan kelinci, industri keripik bayam, pembibitan dan budidaya jamur tiram, pertanian jeruk manis, pertanian apel, pertanian sayur, pertanian jambu merah, industri tingting jahe, pertanian bunga krisan, pertanian bunga mawar, pertanian bunga hias, budidaya samboyo, budaya kuda lumping, peternakan kuda, peternakan hamster, pembuatan sari apel, budaya tari santar, dan drum band, tersedianya lapangan untuk camping, dan kegiatan outbound.

Kampung Wisata Kungkuk didukung oleh 150 tim pengelola serta 30 anggota karang taruna aktif. Selain itu, Kampung Wisata Kungkuk juga memiliki fasilitas pendukung seperti 80 guest house yang dikelola secara mandiri oleh masyarakat setempat. Dalam perkembangannya, desa-desa wisata terus dituntut untuk memiliki sesuatu yang selalu diperbaharui (Samiarta \& Mahagangga, 2016). Oleh karenanya, sarana dan prasarana terus dibenahi oleh masyarakat Kampung Wisata Kungkuk bertujuan untuk menyambut gelombang wisatawan yang datang berkunjung. Wisatawan yang datang berkunjung tidak hanya didominasi oleh wisatawan domestik, tetapi juga wisatawan asing. Animo wisatawan yang tinggi terhadap Kampung Wisata Kungkuk ini menyebabkan tim pengelola dan anggota aktif karang taruna menemui beberapa kendala.

Pada periode analisis situasi yang telah dilakukan oleh tim pengabdian DM UB 2020 (30 Januari - 18 Juni 2020), ditemukan beberapa kendala diantaranya adalah dalam bidang promosi dan penggunaan Bahasa Inggris sebagai sarana berkomuikasi dengan wisatawan asing. Kendala promosi yang dihadapi oleh tim pengelola dan anggota karang taruna adalah kurang gencar dan minimnya promosi yang dilakukan, khususnya dalam bidang digital marketing. Hal ini penting dilakukan mengingat penggunaan teknologi secara tepat dapat memberikan dampak positif pada pembangunan suatu lokasi wisata. Beragam keindahan alam yang berpotensi menjadi tempat wisata dapat dipromosikan melalui informasi digital media sosial. $81 \%$ pengguna internet cenderung melihat pranala pendapat atau tinjauan orang lain terlebih dahulu sebelum berlibur ke suatu tempat (Costache, 2010). Komentar yang diberikan oleh masyarakat dalam promosi media sosial juga dapat digunakan sebagai acuan wisatawan untuk mengunjungi tempat tersebut. Selain permasalahan dalam bidang promosi, penggunaan bahasa asing juga merupakan kendala lain yang dihadapi oleh tim pengelola dan anggota karang taruna. Hal ini disebabkan oleh animo wisatawan mancanegara yang mulai sering berkunjung Kampung Wisata Kungkuk. Minimnya pengetahuan mengenai bahasa asing rupanya masih menjadi kendala yang dihadapi oleh tim pengelola dan anggota karang taruna sehingga hal tersebut dapat menghambat penyampaian info pariwisata di Kampung Wisata Kungkuk. Penggunaan bahasa sebagai media promosi sangat penting dalam menarik dan meningkatkan jumlah kunjungan wisatawan, terutama jika Bahasa yang digunakan sebagai media promosi adalah Bahasa asing (Wibowo \& Kristina, 2018; Setyanto, 2014). Saat ini informasi yang disebarkan masih menggunakan Bahasa Indonesia. Dengan demikian, pelatihan Bahasa Inggris dan Media promosi sangat diperlukan oleh penggiat Kampung Wisata Kungkuk guna meningkatkan perekonomian daerah setempat.

\section{METODE}

Media promosi, penggunaan bahasa asing, dan bidang kewirausahaan merupakan permasalahan yang kerap dialami oleh penggiat wisata di Kampung Wisata Kungkuk (KWK) dalam memaksimalkan potensi desa wisata yang mereka miliki. Untuk memecahkan permasalahan yang sudah diidentifikasi dan dirumuskan oleh tim pengabdian selama periode analisis situasi (30 Januari - 18 Juni 2020), maka tim pengabdian perlu melakukan tindakan pendampingan agar pemecahan masalah di KWK dapat berjalan lancar namun dengan tetap mematuhi protokol kesehatan di tengah era pandemi Covid19. Adapun metode yang dipilih dalam menjembatani permasalahan yang ditemui adalah dengan melakukan pendekatan secara individual dan klasikal.

1. Ceramah bervariasi

Ceramah bervariasi dipilih karena merupakan metode yang berguna untuk 
meningkatkan kemampuan peserta sarasehan (Raden Rizky Amaliah, Abdul Fadhil, 2014). Penggunaan metode ini dipilih juga dengan mempertimbangkan tingkat keberhasilan penyerapan materi yang relatif jika disajikan dengan gambar-gambar, alat peraga, dan tampilan presentasi yang menarik meskipun bobot materi yang diberikan selama pelatihan bersifat padat dan banyak. Materi yang diberikan meliputi: Motivasi berwirausaha, Business Model Canvas (BMC), perencanaan kegiatan dan pencapaian bisnis, Bahasa Inggris yang terdiri dari 7 topik, yaitu; menyambut tamu, menunjukkan arah, obrolan ringan, memperkenalkan spot wisata, memperkenalkan fasilitas, memperkenalkan produk, dan menghadapi komplain.

\section{Demonstrasi}

Metode demonstrasi atau praktek dipilih untuk menunjukkan suatu proses kerja dalam berbagai tahapan (Titin, 2016). Dalam kegiatan sarasehan kewirausahaan, peserta mengisi pre-test sebelum mendapat pendalaman materi. Hal ini dilakukan untuk lebih mengenal kepribadian dan potensi bisnis yang dimiliki oleh para peserta sebelum nantinya materi tentang kewirausahan diberikan. Demonstrasi 7 topik Bahasa Inggris dilakukan oleh instruktur di hadapan peserta dengan mengikuti pembahasan yang tersedia di dalam modul. Metode demonstrasi ini meliputi memperagakan kegiatan menyambut wisatawan asing, memperagakan cara menjelaskan spot wisata, memperagakan cara menjelaskan proses pembuatan produk desa kungkuk seperti keripik apel, dodol jahe, hingga produk pengolahan susu. Selain ini metode demonstrasi ini digunakan dalam kegiatan pelatihan pengelolaan media promosi seperti web, media sosial, dan media promosi lainya untuk meningkatkan wisatawan. Setelahnya, peserta mengikuti demonstrasi instruktur IT dengan menggunakan ponsel untuk penginstalan dan penggunaan aplikasi pembelajaran berbasis android yang telah dirancang oleh tim pengabdian sebelumnya.

3. Latihan

Metode ini digunakan dengan menggabungan penyampaian materi dengan latihan atau percobaan serta memperagakan materi yang telah disampaikan (Akhiruddin et al., 2019) untuk memberikan evaluasi kepada peserta sarasehan agar dapat mempraktikkan materi kewirausahaan dan Bahasa Inggris setelah sebelumnya mendapatkan pendalaman dari tim pemateri. Untuk materi kewirausahaan, peserta bersama-sama menyimak penjelasan dari tim pemateri untuk proses pengisian form BMC. Selanjutnya, latihan dan praktik Bahasa Inggris dilakukan dengan mellibatkan peserta sarasehan untuk melakukan percakapan dua arah. Metode role play menjadi pilihan tim pemateri Bahasa Inggris karena komunikasi peserta dapat dipantau dan dievaluasi saat itu juga.

\section{HASIL DAN PEMBAHASAN}

Kegiatan sarasehan yang dilaksanakan dengan tatap muka dan praktek penggunaan aplikasi pembelajaran berbasis android berjalan dengan tertib, lancar, dan baik. Pertemuan dengan metode ceramah dan demonstrasi dilakukan terlebih dulu sebelum dilanjutkan dengan latihan dan praktek. Kegiatan sarasehan dilaksanakan pada Jum'at, 28 Agustus 2020 pukul 13.00 - 17.00 WIB bertempat di Balai Dukuh Kungkuk dengan dihadiri oleh 4 tim pengabdian, 2 asisten peneliti, serta 4 mahasiswa yang sedang menjalankan program KKNT-DM di Kampung Wisata Kungkuk. Peserta kegiatan berjumlah 20 orang yang terdiri dari para pengurus KWK, pengelola guest house, dan anggota karang taruna serta 3 undangan, yaitu; Kepala Desa Punten, Ketua Kampung Wisata Kungkuk (KWK), dan peliput berita dari Kanal 24.

Pelaksanaan kegiatan sarasehan ini dilakukan oleh empat dosen UB dari tim pengabdian dengan pokok bahasan mengenai: (1) motivasi berwirausaha, (2) Business Model Canvas (BMC), (3) perencanaan kegiatan dan pencapaian bisnis, (4) penggunaan bahasa inggris dalam upaya peningkatan kegiatan promosi dan pelayanan wisatawan asing di KWK. Materi bahasa inggris tersebut terdiri dari 7 topik, yaitu; menyambut tamu, menunjukkan arah, obrolan ringan, memperkenalkan spot wisata, memperkenalkan fasilitas, memperkenalkan produk, dan menghadapi komplain, (5) tutorial instalasi dan cara menggunakan aplikasi pembelajaran berbahasa inggris berbasis android, dan (6) evaluasi materi yang tersedia di modul bahasa inggris.

Keseluruhan materi sarasehan baik di bidang kewirausahaan maupun Bahasa Inggris dapat tersampaikan dengan baik dan terperinci. Kegiatan diawali dengan para panitia membantu peserta sarasehan dalam menggunakan fasilitas dan peralatan penunjang protokol kesehatan Covid19 seperti menggunakan masker, mencuci tangan 10 detik menggunakan sabun cair dan membasuh di air mengalir, mengecek suhu tubuh menggunakan thermogun sebelum memasuki Balai Dukuh Kungkuk, menggunakan hand sanitizer, dan duduk berjarak antar peserta. Diikuti dengan pelaporan dari ketua KWK, DM, serta sambutan Kepala Desa Punten. Acara selanjutnya adalah penyerahan tujuh produk 
luaran DM kepada Kepala Desa Punten dan Ketua KWK oleh ketua pengabdian. Tiga materi kewirausahaan menjadi topik utama di 45 menit pertama acara sarasehan yang kemudian dilanjutkan dengan praktik penggunaan BMC.

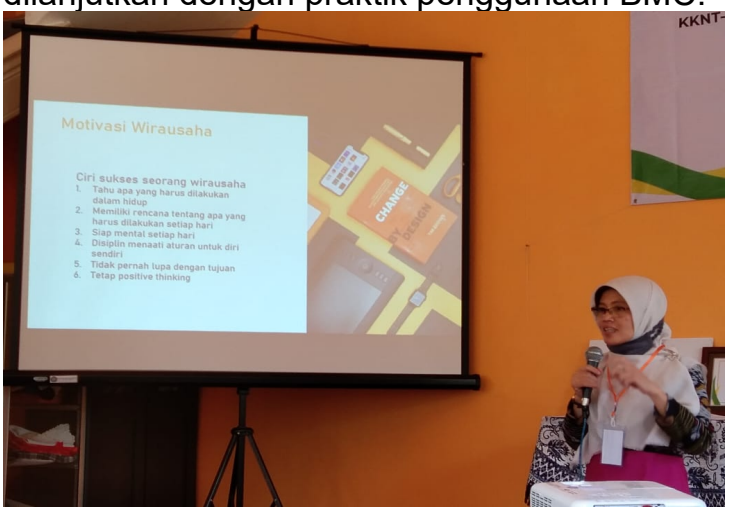

Gambar 1. Pemateri Kewirausahaan

(sumber: dokumentasi tim pengabdian)

Setelah coffee break, pemasangan denah wisata, dan papan petunjuk arah yang disaksikan oleh Ketua Desa Punten dan Ketua KWK, materi kedua yaitu Bahasa Inggris disampaikan kepada peserta dan diikuti dengan latihan dan praktik yang dibimbing langsung oleh tim pemateri.

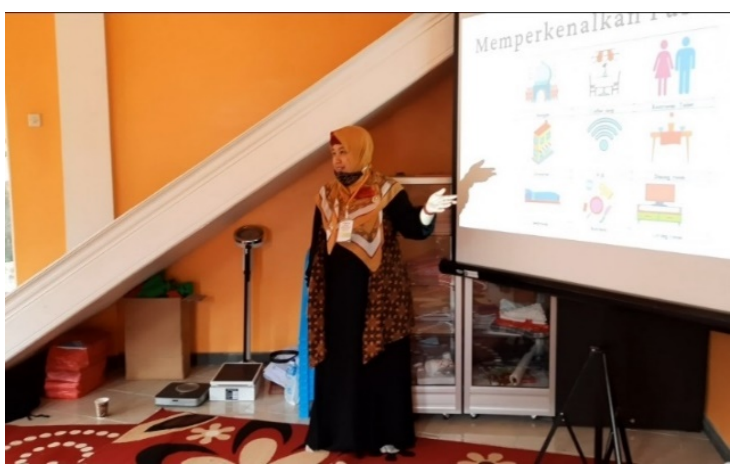

Gambar 2. Pemateri Bahasa Inggris (sumber: dokumentasi tim pengabdian)

Tutorial instal dan penggunaan aplikasi pembelajaran Bahasa Inggris merupakan rangkaian acara terakhir yang disampaikan oleh tim IT DM UB. Selama kegiatan sarasehan berlangsung, terdapat beberapa pertanyaan yang diajukan kepada tim penyaji, secara garis besar inti dari pertanyaan tersebut adalah:

1. Alur penggunaan $B M C$,

2. Penggunaan International Phonetic Alphabet (IPA) secara tepat, dan

3. Penerapan praktik Bahasa Inggris dalam meningkatkan kualitas pelayanan wisatawan asing yang berkunjung ke KWK.

Program upaya peningkatan sadar wisata bagi masyarakat berbasis bahasa dan kewirausahaan pada kegiatan promosi KWK yang sudah terlaksana ini nantinya akan dapat memiliki manfaat guna menambah pengetahuan, keterampilan, percaya diri, dan motivasi diri bagi penggerak wisata di KWK dalam upaya peningkatan kualitas layanan, khususnya di bidang kewirausahaan dan penggunaan bahasa asing dalam menyambut wisatawan yang datang berkunjung.

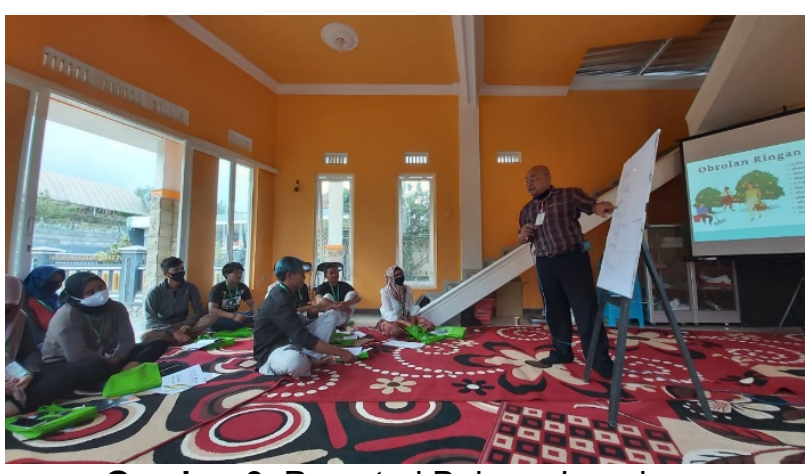

Gambar 3. Pemateri Bahasa Inggris memberikan instruksi praktek dan latihan bagi peserta (sumber: dokumentasi tim pengabdian)

Disamping itu dengan adanya aplikasi pendukung dalam pembelajaran Bahasa Inggris, proses belajar penggerak wisata di KWK akan lebih menarik, bervariasi, dan fleksibel. Hal ini mengingat bahwa aplikasi pembelajaran berbasis android ini merupakan produk DM yang memiliki beberapa keunggulan, diantaranya; ukuran aplikasi ringan (20,70 MB), tidak memerlukan kuota internet untuk pengunaannya setelah aplikasi terinstal di ponsel, tidak memerlukan izin akses apapun ke ponsel sehingga user dapat menggunakan aplikasi pembelajaran secara aman tanpa khawatir data pribadi disalahgunakan oleh developer, dan disertai dengan audio yang membantu user untuk melafalkan Bahasa Inggris secara baik dan benar.

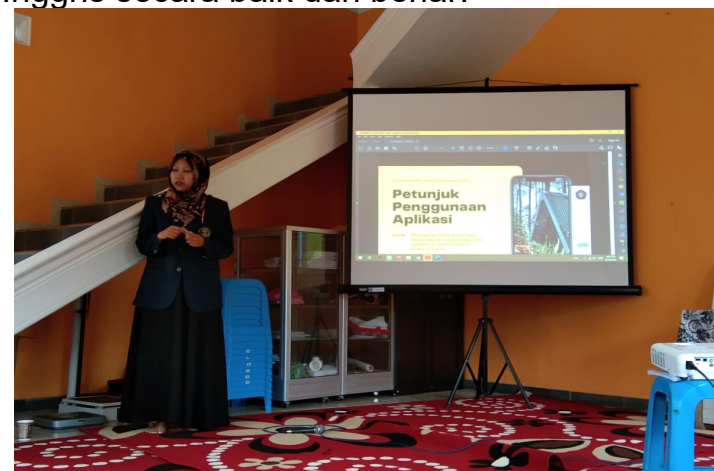

Gambar 4. Tutorial pemasangan dan penggunaan aplikasi pembelajaran berbasis android oleh tim IT (sumber: dokumentasi tim pengabdian) 
Tabel 1. Feedback Pelatihan

\begin{tabular}{llcc}
\hline No & Pernyataan & Ya & Tidak \\
\hline 1. & $\begin{array}{l}\text { Materi yang } \\
\text { diberikan sesuai } \\
\text { dengan } \\
\text { kebutuhan } \\
\text { penggat wisata }\end{array}$ & $15 \%$ \\
\hline 2. & $\begin{array}{l}\text { Memahami } \\
\text { materi yang } \\
\text { disampaikan }\end{array}$ & & \\
\hline 3. & $\begin{array}{l}\text { Materi sangat } \\
\text { bermanfaat bagi }\end{array}$ & $10 \%$ & $5 \%$ \\
& $\begin{array}{l}\text { kemajuan desa } \\
\text { wisata }\end{array}$ & & \\
\hline 4. & $\begin{array}{l}\text { Pemateri } \\
\text { kompeten dalam } \\
\text { menyampaikan }\end{array}$ & & \\
\hline
\end{tabular}

\section{SIMPULAN DAN SARAN}

Hasil kegiatan DM secara garis besar mencakup beberapa komponen yang dapat dijabarkan sebagai berikut; (1) keberhasilan menghasilkan 7 produk luaran dalam program DM, (2) keberhasilan target jumlah peserta sarasehan, (3) ketercapaian tujuan pelatihan, (4) ketercapaian target materi kewirausahaan, Bahasa Inggris, dan penggunaan aplikasi yang telah direncanakan, dan (5) kemampuan peserta dalam penguasaan materi.

Kegiatan pengabdian DM UB 2020 sejauh ini telah menghasilkan beberapa produk luaran, diantaranya adalah: (1) buku saku kewirausahaan, (2) buku saku Bahasa Inggris, (3) denah lokasi wisata di Kampung Wisata Kungkuk, (4) papan petunjuk arah menuju lokasi wisata yang ada di Kampung Wisata Kungkuk, (5) website resmi kampung wisata, (6) aplikasi pembelajaran berbasis android, dan (7) buku profil desa.

Target peserta sarasehan yang direncanakan adalah sejumlah 20 orang yang terdiri dari pengurus $\mathrm{KWK}$, pengelola guest house, dan anggota karang taruna. Dalam pelaksanaannya, kegiatan sarasehan tersebut diikuti oleh 20 orang. Dengan demikian dapat dikatakan bahwa target peserta sarasehan dapat tercapai $100 \%$.

Ketercapaian tujuan penyampaian materi kewirausahaan dan Bahasa Inggris sudah baik secara garis besar, tetapi keterlambatan peserta ketika open gate membuat waktu penyampaian materi menjadi terpotong. Sehingga para pemateri harus memanfaatkan waktu yang tersisa dengan efisien. Namun, dilihat dari hasil peserta dalam mengisi latihan kewirausahaan (BMC) serta praktek dan latihan bercakap-cakap menggunakan Bahasa Inggris, maka dapat disimpulkan bahwa tujuan sarasehan telah dapat tercapai.
Ketercapaian target materi dalam kegiatan sarasehan ini cukup baik karena materi yang telah direncanakan sudah tersampaikan secara keseluruhan. Materi pengabdian yang disampaikan adalah:

1. Kewirausahaan,

2. Bahasa Inggris, dan

3. Penggunaan aplikasi pembelajaran.

Kemampuan peserta dilihat dari penguasaan materi masih kurang dikarenakan waktu pertemuan dengan tim pengabdian yang terbatas, waktu yang singkat dalam penyampaian materi, dan kemampuan peserta sarasehan yang tentunya berbeda-beda. Hal ini dipengaruhi oleh beberapa factor, diantaranya jumlah materi yang banyak tetapi harus disampaikan hanya dalam waktu sehari. Sehingga peserta tidak banyak memiliki ruang dan waktu untuk mempraktekkan dan memahami secara penuh materi yang disajikan.

Ditinjau dari keempat aspek diatas, sarasehan dalam upaya peningkatan sadar wisata bagi masyarakat berbasis bahasa dan kewirausahaan pada kegiatan promosi KWK ini dapat dikatakan berhasil. Indicator keberhasilan juga dapat dilihat dari feedback instrument yang telah diisi oleh peserta di akhir acara yang menunjukkan kepuasan peserta setelah mengikuti kegiatan sarasehan.

\section{UCAPAN TERIMAKASIH}

Ucapan terima kasih penulis sampaikan kepada LPPM UB yang telah mendanai segala kegiatan tim DM, perangkat Desa Punten \& segenap penggerak wisata di KWK sebagai mitra pengabdian yang telah menerima, mendukung, dan membantu terlaksanannya kegiatan pengabdian ini.

\section{DAFTAR RUJUKAN}

Akhiruddin, Sujarwo, Atmowardoyo, H., \& Nurhikmah. (2019). BAHAN AJAR: BELAJAR DAN PEMBELAJARAN.

Antara, M., \& Arida, N. S. (2015). Panduan Pengelolaan Desa Wisata Berbasis Potensi Lokal. Konsorium Riset Pariwisata Universitas Udayana, 23.

Arida, I. N. S., \& Pujani, L. K. (2017). Kajian Penyusunan Kriteria-Kriteria Desa Wisata Sebagai Instrumen Dasar Pengembangan Desawisata. Jurnal Analisis Pariwisata, 17(1), 1-9.

Costache, M. (2010). Qualman, Eric. (2009) Socialnomics: how social media transforms the way we live and do business. John Wiley \& Sons, New Jersey. Journal of Comparative Research in Anthropology and Sociology, 1(2), 225228.

http://search.proquest.com/docview/1040 
722412 ?accountid $=28180 \% 5$ Cnhttp: $/ / x+6$ nc6eu9q.search.serialssolutions.com/?ctx ver=Z39.88-

2004\&ctx_enc=info:ofi/enc:UTF-

8\&rfr_id=info:sid/ProQ:pqrl\&rft_val_fmt=in fo:ofi/fmt:kev:mtx:journal\&rft.genre=unkn own\&rft.jtitle=

Raden Rizky Amaliah, Abdul Fadhil, S. N. (2014). Penerapan Metode Ceramah dan Diskusi dalam Meningkatkan Hasil Belajar PAl di SMA Negeri 44 Jakarta. Studi AlQur'an; Membangun Tradisi Berfikir Qur'an, 10(2), 119-131. http://journal.unj.ac.id/unj/index.php/jsq/ar ticle/view/4441

Samiarta, I. G., \& Mahagangga, I. G. A. O. (2016). PERKEMBANGAN DESA WISATA DI KABUPATEN BADUNG (Studi Kasus Desa Wisata Baha). Jurnal Destinasi Pariwisata, 4(2), 114. https://doi.org/10.24843/jdepar.2016.v04.i 02.p20

Sastrayuda, G. (2010). KONSEP PENGEMBANGAN KAWASAN WISATA SPA (SOLUS PER AQUA). 1-17.

Setyanto, A. (2014). Pentingnya Penguasaan Bahasa dan Budaya Asing Sebagai Pendukung Utama Sektor Pariwisata. Jurnal Pariwisata: FIB Universitas Brawijaya, 1(1), 1-12.

Sukma, A. I. N. (2014). Buku Ajar Pariwisata Berkelanjutan.

Titin, S. (2016). Pengaruh Metode Pembelajaran Praktik Terhadap Motivasi Dan Hasil Belajar Pendidikan Agama Islam Siswa Kelas IV Sekolah Dasar. Studia Didkatika Jurnal IImiah Pendidikan, 10(2), 1-18.

Wibowo, A., \& Kristina, D. (2018). EFEKTIVITAS PENGGUNAAN BAHASA INGGRIS DALAM MEDIA PROMOSI PARIWISATA SOLO RAYA MENUJU PEMBANGUNAN SISTEM ONLINE TOURISM PROMOTION Agus Hari Wibowo, Diah Kristina Abstrak PENDAHULUAN Perkembangan teknologi informasi dan komunikasi dalam beberapa tahun ter. Cakra Wisata, 19, 1222. 